\title{
THE EFFECT OF THE BIG BOOK MEDIA USAGE TO SIMPLE SENTENCES' READING ABILITY FOR THIRD GRADER WITH INTELLECTUAL DISABILITY ON ELEMENTARY SCHOOL FOR SPECIAL NEEDS
}

\author{
Putri Karlis Ramadhani ${ }^{a}$, Usep Kustiawan ${ }^{\text {b }}$ \\ ${ }^{a b}$ Department of Special Education, State University of Malang, Indonesia \\ E-mail : putrikarlis.pr@gmail.com
}

\begin{abstract}
Child with mild intellectual disability has a resistance of 50-80 IQ intelligence below normal IQ. The purpose of this study is to analyze the effect of the big book media usage towards reading ability of simple sentences for students with mild intellectual disability. The study used the pre-experimental method with one group pretest-posttest design. The data analysis was tested by wilcoxon signed ranks test with significant level 0.05 and 5 students as sample. The results found that there was the effect of the big book media usage towards reading ability of simple sentence for students with mild intellectual disability. Suggestions for the teachers to apply the big book media as complement in learning process for the students with mild intellectual disability.
\end{abstract}

Keywords: big book media, read a simple sentence, mild intellectual disability

In everyday life, language has a very important role for humans as a means to express and communicate their feelings and hearts to others. In learning activities, language also has a major role, including in the education of children with special needs, especially for children with intellectual disability. Intellectual disability is a condition where a person experiences barriers to the development of intelligence, so that it does not reach the optimum stage of development. Intellectual disability is a term for someone who has the intellectual power is below average (Soemantri, 2012). Child with intellectual disability is a child who has a low intelligence level of development so as to be able to pursue development tasks require education and counseling services in particular. Based on the type, children with intellectual disability can be classified into three categories: a) severe intellectual disability or afford care, b) moderate intellectual disability or capable coach, and mild intellectual disability or capable students (Soemantri, 2012). Children with mild intellectual disability is one of the children who have pervasive developmental disorder, with a level of intelligence between 50-80 (Pratiwi, et al. 2013). They were classified as having a very low mental development so as to pursue development tasks urgently need education and counseling services in particular. Children with mild intellectual disability have ability in social and motor skill but their academic skills only mastered in specific fields (Effendi, 2009).

Children with mild intellectual disability or capable learners is one of the children who have mental developmental disorder. They still have ability in social and motor skill but their academic skills only mastered in specific fields. As a student, they were not able to follow the regular school program. They still have the ability that can be developed through education although the results were not optimal. Capabilities that can be developed by children with mild intellectual disability, among others: (1) reading, writing, spelling and arithmetic; (2) adaptation and unreckon on others; and (3) simple skills for the benefit of future work (Effendi, 2009: 90).

Children with intellectual disability have limitation on attention, memory, academic, and language aspect. In fact, children with intellectual disability can still learn to read, write and simple calculate, but these capabilities are not perfectly meet the skills learned in the classroom (Somantri, 2012). One of the obligations of the educators at the school are able to develop their talents and abilities of children with intellectual disability. One important children with intellectual disability' ability to develop is the ability to read. With the ability to read, children with intellectual disability can explore the surrounding environment. Tarigan (2008:7-8) explains that reading is a process that is performed or used by a reader to obtain the messages conveyed by the author through the medium of words or written language. Through the development of reading skills, children are expected to mild intellectual disability can acquire new knowledge, and thereby many skills possessed or controlled.

One media appropriate learning to develop students with intellectual disability' reading abilities is the media Big Book. Big Book is a illustrated story 
media appropriate for the learning activities in the classroom. This illustrated storybook with a large size and contents tailored to the learning needs of children (Tim Penulis Buku Sumber Dosen LPTK, 2014). There is an assortment of images and text that has the characteristics of a colorful, allowing the child may be attracted to open and view the contents inside the Big Book. Large font sizes allows children easy to read every sentence in it.

There are many benefits contained in the media Big Book, namely: (1) instill reading habit to the child, because the size of large text and each word or phrase is easy to understand and the use is adapted to grade level and needs of the child; (2) get children to read aloud in front of the classmates, and it can foster self-confidence in children, because they have been successful as an early reader, and thereby children are more motivated to learn to read; (3) through a fun learning environment, children do not feel afraid or lazy with the assignment of teachers; and (d) through the atmosphere pleasant reading in class, children can assume that they were well read. Slowly, children began to love reading and also motivated to read at home anywhere elsewhere.

\section{METHOD}

This research was conducted with a quantitative approach to the pre-experimental design with one group pre-test - post-test design with no control group. Pretest is used to determine the initial ability of students to understand the material that will be given in class. After that, given the treatment of learning to use the media Big Book. After completion of treatment, do post-test to determine whether there is the effect of the application of the book to the big media student learning outcomes.

In this research there are two variables, namely the dependent variable and independent variables. The dependent variable in the form of reading ability in children with mild intellectual disability, and the independent variable is Big Book instructional media. Subjects were students with mild intellectual disability or capable of learners in Grade 3 at the SDLB Pembina Tingkat Nasional, Lawang, Malang, with the number of 5 people.

Test (pre-test and post-test) to measure the ability to read simple sentences. Instruments used include learning to use the media Big Book and reading ability test. Simple sentence tested at pre-test and post-test that sentence su-su sa-pi, ku-da ma-kan, ma-ta i-kan, i-kan di la-ut, dan a-ku su-ka a-yam.

To test the average difference in students' ability to read simple sentences were calculated using nonparametric test ranking marked Wilcoxon Signed Ranks Test.

\section{FINDINGS AND DISCUSSION}

\section{Findings}

This study was conducted to determine the effect of the use of media Big Book of the ability to read simple sentences for child with mild intellectual disability. The results showed the following data (Tabel 2).

Based on the data table 2 summarize the results of the reading, it can be seen that significant differences in reading ability between before and after the child is given treatment using instructional media Big Book.

Table 1. Learning instrument for simple sentence' reading ability

\begin{tabular}{|c|c|c|c|c|}
\hline \multirow[t]{2}{*}{ Score } & \multicolumn{4}{|c|}{ Measured Aspects } \\
\hline & $\begin{array}{c}\text { Recognizing letter } \\
\text { shape }\end{array}$ & $\begin{array}{c}\text { Recognizing linguistic } \\
\text { element }\end{array}$ & Voicing writing & Reading speed \\
\hline 1 & $\begin{array}{l}\text { If child only } \\
\text { recognize } 7 \text { first } \\
\text { letters }\end{array}$ & $\begin{array}{l}\text { If child only recognize } \\
\text { phoneme }\end{array}$ & $\begin{array}{l}\text { If child doesn't fluent to } \\
\text { read and need guidance }\end{array}$ & $\begin{array}{l}\text { If child takes more than } \\
10 \text { seconds to spell }\end{array}$ \\
\hline 2 & $\begin{array}{l}\text { If child only } \\
\text { recognize } 14 \text { first } \\
\text { letters }\end{array}$ & $\begin{array}{l}\text { If child only recognize } \\
\text { phoneme and word }\end{array}$ & $\begin{array}{l}\text { If child is able to say one } \\
\text { word smoothly }\end{array}$ & $\begin{array}{l}\text { If the child takes } 8-10 \\
\text { seconds to spell }\end{array}$ \\
\hline 3 & $\begin{array}{l}\text { If child only } \\
\text { recognize } 21 \text { first } \\
\text { letters }\end{array}$ & $\begin{array}{l}\text { If child only recognize } \\
\text { phoneme, word, and } \\
\text { phrase }\end{array}$ & $\begin{array}{l}\text { If child know how to read } \\
\text { a simple sentence with } \\
\text { occasional guide }\end{array}$ & $\begin{array}{l}\text { If the child takes } 5 \\
\text { seconds to spell }\end{array}$ \\
\hline 4 & $\begin{array}{l}\text { If child only } \\
\text { recognize } 28 \text { first } \\
\text { letters }\end{array}$ & $\begin{array}{l}\text { If child only recognize } \\
\text { phoneme, word, phrase, } \\
\text { and simple sentence }\end{array}$ & $\begin{array}{l}\text { If the children fluent in } \\
\text { reading simple sentences } \\
\text { independently }\end{array}$ & $\begin{array}{l}\text { If the child takes less } \\
\text { than } 5 \text { seconds to spell }\end{array}$ \\
\hline
\end{tabular}


The result of the calculation of raw data in Table 2 , and then plotted on the graph 1 summary data of pretest and posttest reading simple sentences students following a mild intellectual disability.

Based on the first graph is known that before being treated, pre-test results indicate the number of initial ability scores by $31 \%$ to $69 \%$. Meanwhile, after given treatment, post-test results show the percentage of $88 \%$ to $100 \%$. This shows a significant difference ability in the child's reading assessment. It can be concluded that the media Big Book has an influence on students with intellectual disability learning.

Table 2: Summary data of reading ability

\begin{tabular}{cccccccc}
\hline No & Name & Sum of Pre-test Score & Average & Percentage & Sum of Post-test Score & Average & Percentage \\
\hline 1 & $\mathrm{Hs}$ & 5 & 1.25 & $31 \%$ & 15 & 3.75 & $94 \%$ \\
\hline 2 & $\mathrm{Ar}$ & 6 & 1.5 & $38 \%$ & 14 & 3.5 & $88 \%$ \\
\hline 3 & $\mathrm{Cy}$ & 4 & 1 & $25 \%$ & 14 & 3.5 & $88 \%$ \\
\hline 4 & $\mathrm{Dt}$ & 7 & 1.75 & $44 \%$ & 16 & 4 & $100 \%$ \\
\hline 5 & $\mathrm{Yn}$ & 11 & 2.75 & $69 \%$ & 16 & 4 & $100 \%$ \\
\hline & Total & 33 & 8.25 & $206 \%$ & 75 & 18.75 & $469 \%$
\end{tabular}

Graph 1 Summary Data of Pre-test and Post- test Reading Ability of Simple Sentences of Mild Intellectual Disability Students

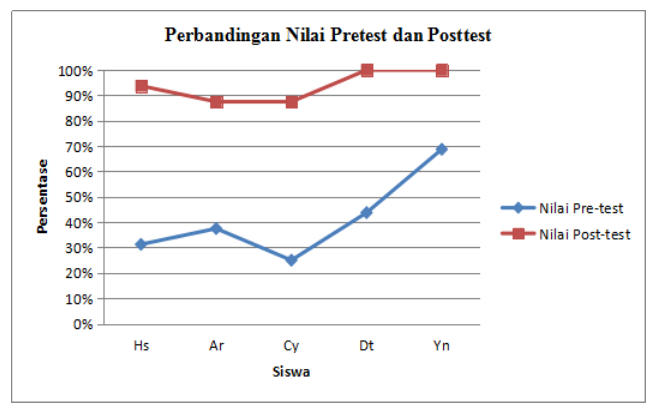

\section{Discussion}

Results of the study found that prior to being treated, the number of overall score of 5 students is 33 with an average of 8.25 . The score entered into the results of the pre-test students to read simple sentences. The results using Wilcoxon Signed Ranks Test data shows students before being given treatment using media Big Book has a minimum score of 4.00 and a maximum score of 11.00 with an average ability to read simple sentences only at 6.60 .

Students with mild intellectual disability' learning ability is not comparable with regular students' learning ability of their age. Students with mild intellectual disability can still learn to read, write and count even if done in a simple appropriate capabilities and with proper guidance.

After being given the treatment, post-test score increased to 75 with an average of 18.75 . The result of the ability to read simple sentences given after treatment obtained a minimum score of 14.00 and a maximum score of 16.00 with an average of 15.00 .

Results of statistical analysis to test the hypothesis shows the significance value of 0.042 (below 0.05).
Thus, it means that Ho is rejected. It can be concluded that there are differences or significant influence between pre-test and post-test mild intellectual diability students in learning using learning media Big Book.

The results are consistent with research Wibowo (2014) and also Yuniati (2014). According Wibowo (2014), Big Book study the use of media is very influential on early childhood language development. In storytelling and discussions using the media Big Book, children not only listen to the explanations of the teacher, but also be able to speak his mind and express ideas and imagination associated with a story or a picture. According Yuniati (2014), after using the media Big Book students' early reading skills has increased. Improvement can be seen from the process and the results, stating that students become more active and learning more interactive. Students understand learning materials well as media Big Book presents a picture that is easily understood.

Attractive learning environment and encourage children to take an active role can motivate children to express ideas, ideas, or story well and children development is develop optimally after the experiment using instructional media Big Book. 


\section{CONCLUSION AND SUGGESTION}

Based on the results of the discussion, it can be concluded that there are significant use of the Big Book of the ability to read simple sentences of student with mild intellectual disability. Big Book as a media can improve the students with mild intellectual disability in reading simple sentences. Based on the findings of

\section{REFERENCES}

Effendi, Muhammad. 2009. Psikopedagogi Anak Berkebutuhan Khusus. Jakarta: Rineka Cipta.

Mangunsong, F. 2009. Psikologi dan Penddikan Anak Berkebutuhan Khusus. Depok: LPSP3 UI

Pratiwi, P. P, dkk. 2013. Kiat Sukses Mengasuh Anak Berkebutuhan Khusus. Yogyakarta : Ar-Ruzz Media.

Soemantri, S. 2012. Psikologi Anak Luar Biasa. Bandung : Refika Aditama.

Tarigan, H.G. 2008. Membaca Sebagai Suatu Keterampilan Berbahasa. Bandung : Angkasa this research are expected to be an alternative media of learning, especially on thematic subjects as well as in other subjects. Teachers can use the media Big Book as supporting learning activities for improving the quality of learning. In a subsequent study is expected to enhance the use of media Big Book that allows students to use and more interesting to read in learning.

Tim Penulis Buku Sumber Untuk Dosen. 2014. Pembelajaran Literasi Kelas Awal Di LPTK. Jakarta : USAID

Wibowo, Cintiya E. 2014. Pengaruh Media Cerita Big Book Terhadap Perkembangan Bahasa Anak Kelompok Bermain Fatimah Purbayan Baki Sukoharjo. Skripsi. Surakarta. Universitas Negeri Surakarta.

Yuniati, 2014. Peningkatan Kemampuan Membaca Permulaan Melalui Media Big Book's Siswa Kelas IB SDN Mangiran Kecamatan Srandakan. Skripsi. Yogyakarta. Universitas Negeri Yogyakarta. 